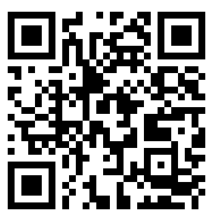

Submitted:

12-11-2019
Revised:

13-02-2020

Journal An-Nafs: Kajian Penelitian Psikologi

https://ejournal.iai-tribakti.ac.id/index.php/psikologi e-ISSN: 2549-6166 p-ISSN: 2528-0600

DOI: $10.33367 / p s i . v 5 i 2.958$

\title{
HUBUNGAN SPIRITUAL WELL-BEING DAN KECERDASAN EMOSI PADA SIKAP TOLERANSI BAGI KAUM REMAJA
}

\author{
Raja Oloan Tumanggor ${ }^{1}$, Heni Mularsih ${ }^{2}$ \\ 1rajat@fpsi.untar.ac.id, 2henim@mku.untar.ac.id \\ Universitas Tarumanagara Jakarta
}

\begin{abstract}
This study analyzes the relationship between spiritual well-being and emotional intelligence to tolerance for adolescents. Spiritual well-being is the affirmation of life concerning, oneself, others, the environment, and God. This relation can be developed into four interconnected domains of human existence concerning spiritual well-being; oneself, community, environment, and God. Emotional intelligence is one of the keys to success in life. So, people are aware of themselves and others, have motivation and optimism. The study took data from 1113 adolescents from five provinces (DKI, West Java, Lampung, North Sumatra, and Central Java), aims to find out the relationship between spiritual well-being and emotional intelligence on tolerance. From the analysis of data using correlation and regression found that spiritual well-being is related to tolerance $\left(r=0.844\left(^{* *}\right), p=000<0.001\right)$, and spiritual well-being affects the attitude of tolerance ( $r 2=.699, t=30896, p<.001$ ). Likewise emotional intelligence is related to tolerance for adolescents $\left(r=0.844\left({ }^{* *}\right), p=000<0.001\right)$ and emotional intelligence influences tolerance $(r 2=.712, t=-5102, p<.001)$. The higher level of spiritual well-being and emotional intelligence, the better the tolerance attitude of adolescents.
\end{abstract}

Keywords: adolescents, emotional intelligence, spiritual well-being, tolerance

\section{Abstrak}

Penelitian ini menganalisa hubungan spiritual well-being dan kecerdasan emosional pada sikap toleransi bagi kaum remaja. Spiritual well-being adalah afirmasi hidup dalam berelasi dengan, diri sendiri, sesama, lingkungan, dan Tuhan. Relasi ini bisa dikembangkan menjadi empat domain yang saling berhubungan dari eksistensi manusia menyangkut kesejahteraan spiritual, yaitu, diri sendiri, komunitas, lingkungan, dan Tuhan. Sementara kecerdasan emosional merupakan suatu indikator kesuksesan hidup. Orang yang memiliki kecerdasan emosional tahu akan situasi diri serta orang lain, mempunyai dorongan untuk selalu optimis. Penelitian yang mengambil data 1113 kaum remaja dari lima propinsi (DKI, Jawa Barat, Lampung, Sumatera Utara, dan Jawa Tengah) ini bertujuan mengetahui hubungan antara spiritual well being dan kecerdasan emosional pada sikap toleransi. Dari analisa data dengan menggunakan korelasi dan regresi ditemukan bahwa spiritual wellbeing berhubungan dengan sikap toleransi $\left(r=0,844\left(^{* *}\right), p=000<0,001\right)$, dan spiritual well-being berpengaruh terhadap sikap toleransi $\left(\mathrm{r}^{2}=.699, \mathrm{t}=30896, \mathrm{p}<.001\right)$. Demikian juga kecerdasan emosi berhubungan dengan sikap toleransi bagi kaum remaja $\left.\left(\mathrm{r}=0,844{ }^{* *}\right), \mathrm{p}=000<0,001\right)$ dan kecerdasan emosi berpengaruh terhadap sikap toleransi $\left(\mathrm{r}^{2}=.712, \mathrm{t}=-5102, \mathrm{p}<.001\right)$. Temuan dari penelitian ini adalah semakin tinggi tingkat kesejahteraan spiritual dan kecerdasan emosional maka semakin baik juga sikap toleransi kaum remaja.

Kata Kunci: kaum remaja, kecerdasan emosional, spiritual well-being, toleransi 
Hubungan Spiritual Well-Being | Raja Oloan Tumanggor, Heni Mularsih

\section{PENDAHULUAN}

Pada awal tahun 2018 terjadi beberapa peristiwa penyerangan terhadap para tokoh agama di Indonesia, misalnya K.H. Umar Basri pada 27 Januari di Kabupaten Bandung, Ustaz Prawoto pada 1 Februari di Bandung dan Romo Karl Edmund Prier, SJ pada 11 Februari di Sleman (Gerintya, 2018). Aneka aksi kekerasan ini merupakan salah satu bentuk perilaku intoleransi di masyarakat, khususnya intoleransi antar penganut agama. Menurut Deklarasi Eliminasi segala bentuk intoleransi dan diskriminasi yang didasarkan pada agama dan kepercayaan, intoleransi dipahami sebagai tindakan membedakan, mengabaikan, melarang seseorang berdasarkan agama atau kepercayaan yang tujuannya meniadakan atau mengurangi pengakuan, penikmatan, atau pelaksanaan hak asasi manusia (Gerintya, 2018).

Menurut catatan Setara Institut tahun 2016 terdapat 208 peristiwa pelanggaran kebebasan beragama/berkeyakinan dengan 270 bentuk tindakan. Terdapat 130 tindakan dilakukan oleh aktor non negara dengan pelaku tertinggi adalah kelompok warga sebanyak 42 tindakan. Pada tahun 2017 ada 155 peristiwa pelanggaran kebebasan beragama/berkeyakinan dengan 201 bentuk tindakan. Terdapat 126 perbuatan yang dilakukan bukan oleh aktor negara, dimana pelaku terbanyak adalah kelompok warga dengan 28 tindakan. Di beberapa kota di Indonesia terdapat beberapa kasus terkait praktik intoleransi yang dimulai dari penyebaran informasi yang salah dan kebencian terhadap suatu kepercayaan, pembatasan hak asasi manusia atas kepercayaan tertentu, serta membiarkan kelompok intoleran melakukan aksinya (Gerintya, 2018).

Praktik intoleransi ini tidak jarang melibatkan kaum remaja. Kaum remaja merupakan sekelompok manusia yang sedang berjuang mencari jati dirinya dan sekaligus menjadi golongan penentu dalam kemajuan generasi yang akan datang. Suatu bangsa akan maju bila kaum remajanya mendapat pendampingan yang memadai. Namun, dalam situasi sekarang ini kaum remaja menjadi pelaku tindak intoleran akibat pengaruh lingkungannya. Kasus intoleransi menjadi masalah serius dan bisa berakibat negatif bagi kaum remaja kalau tidak segera diatasi (Supriyanto \& Wahyudi, 2017).

Banyak faktor yang membuat kaum remaja jatuh dalam aksi-aksi intoleran dalam masyarakat. Media sosial membuat kaum remaja mudah memperoleh informasi dari paham kaum radikal. Tidak jarang kaum remaja merupakan target mudah untuk organisasi ekstrim yang menyebarkan ideologi radikal yang mengancam pluralisme di Indonesia. Informasi tentang paham radikal dengan mudah sampai ke kalangan kaum remaja. Selain itu remaja yang kurang mendapat pembinaan spiritual memadai dari 
Hubungan Spiritual Well-Being | Raja Oloan Tumanggor, Heni Mularsih

institusi keagamaan dan keluarganya akan semakin rentan dengan berbagai pengaruh negatif termasuk sikap intoleran.

Untuk membentengi kaum remaja dari sikap intoleran perlu diperhatikan aspek spiritual well-being dan kecerdasan emosionalnya. Spiritual well-being adalah afirmasi hidup dalam berelasi dengan, diri sendiri, komunitas lingkungan, dan Tuhan (Fisher, 2010). Spiritual Well-Being merupakan indikasi kualitas hidup seseorang dalam dimensi spiritual atau indikasi dari kesehatan spiritualnya (Ellison, 1983; Bufford et al., 2018). Orang yang memiliki spiritual well-being yang baik dilihat dari situasi sejauh mana dia memiliki relasi yang baik dengan diri sendiri, sesama, lingkungan dan Tuhan. Masalah spiritual well-being tidak hanya menyangkut relasi dengan Tuhan atau Ilahi, tapi juga akumulasi relasi yang baik dan harmonis dengan diri sendiri, sesama, dan lingkungannya.

Sementara kecerdasan emosional merupakan himpunan dari kecerdasan sosial yang melibatkan kemampuan perasaan dan emosi baik kepada diri sendiri ataupun orang lain, mampu memilah dan menggunakan informasi ini guna membimbing pikiran dan tindakan. Dengan kecerdasan emosi yang tinggi orang akan mampu untuk memberikan persepsi secara tepat, menilai, mengerti, dan mengungkapkan perasaan dengan benar (Goleman, 1995). Berdasarkan kondisi intoleran di atas, penelitian ini ingin mengetahui dan menguji hubungan spiritual well-being dan kecerdasan emosional terhadap sikap toleransi bagi kaum remaja.

Kata 'toleransi' berasal dari bahasa Latin tolerare yang artinya adalah membiarkan. Dalam Sementara kata Inggeris tolerance berarti membiarkan, mengakui dan menghormati kekpercayaan orang lain tanpa butuh persetujuan. Maka toleransi merupakan sikap mampu menerima pendapat orang lain. Hal ini bukan bermaksud menyingkirkan pendapat yang diyakininya benar, melainkan tetap kuat dalam prinsip yang tercermin dalam sikap kokoh mengikuti keyakinannya. Menurut Khisbiyah (2007) toleransi merupakan kemampuan untuk menahan hal-hal yang tidak disetujui guna menjalin relasi sosial yang makin baik. Toleransi mengandaikan kemampuan menerima dan menghargai pendangan, pendapat, nilai orang lain yang beda dengan kita. Sementara intoleransi adalah ketidakmauan menghargai dan menerima perbedaan.

Dari uraian di atas sikap toleransi dapat dipahami sebagai sikap bersedia menerima keragaman dan kepercayaan yang diyakini oleh pihak/golongan lain. Pengakuan ini bukan cuma pada kesamaan derajat untuk menata negara dan masyarakat, tapi juga pada perbedaan pada cara merenungkan dan melaksanakan ibadah (Bahari, 2010). Sikap toleransi merupakan kesadaran seseorang untuk menghargai, menghormati, membiarkan, dan memperbolehkan pendirian, pandangan, keyakinan, kepercayaan, serta 
memberikan ruang bagi pelaksanaan kebiasaan, perilaku, dan praktik keagamaan orang lain yang berbeda atau bertentangan dengan pendirian sendiri dalam rangka membangun kehidupan bersama dan hubungan sosial yang lebih baik (Ghufron, 2016). Dengan adanya toleransi, persatuan dan kesatuan bangsa akan dapat dilestarikan. Pembangunan dapat diupayakan dan dilanjutkan, sehingga kesenjangan bisa diminimalkan. Relasi antar warga beragama berdasar pada prinsip kekeluargaan yang baik, bersama-sama menghadapi musuh serta mau membantu orang menderita (Ghufron, 2016).

Kaum remaja adalah sekelompok orang yang mengalami masa peralihan dari masa anak dan masa dewasa antara umur 11 sampai 21 tahun. Masa remaja dimulai dengan perubahan fisik yang cepat, pertambahan berat dan tinggi badan yang dramatis, perubahan bentuk tubuh, dan perkembangan karakteristik seksual seperti pembesaran buah dada, perkembangan pinggang dan kumis dan dalamnya suara. Pada perkembangan ini diperoleh pencapaian kemandirian dan menonjolkan identitas, karena pemikiran yang makin logis, abstrak dan idealistis serta menghabiskan banyak waktu di luar keluarga. Jadi pada masa remaja terjadi perubahan biologis, koqnitif dan sosial emosional (Santrock, 2003). Masa remaja adalah masa peralihan dari masa anak-anak menuju masa dewasa dimana kaum remaja mengalami perkembangan di berbagai aspek kehidupannya, sehingga mereka siap menyongsong masa dewasa (Rumini \& Sundari H.S., 2004).

Menurut Fisher (2010) Spiritual Well-Being merupakan afirmasi hidup dalam berelasi dengan Tuhan, diri sendiri, komunitas dan lingkungan secara bersama. Relasi ini kemudian dikembangkan dalam empat domain yang saling berhubungan. Keempat domain itu meliputi pertama, domain personal, dimana seseorang berhubungan dengan dirinya menyangkut makna, tujuan, dan nilai dalam hidup. Kesadaran ini menjadi kekuatan yang menentukan dari roh manusia dalam mencari identitas diri. Kedua, domain komunal tampak dalam kualitas dan kedalaman relasi interpersonal antara diri sendiri dengan orang lain, berkaitan dengan moralitas, budaya dan agama. Relasi ini diungkapkan dalam cinta, pengampunan, kepercayaan, harapan dan iman. Ketiga, domain lingkungan menyangkut pemeliharaan fisik dan biologis, rasa memiliki dan kagum dan gagasan kesatuan dengan lingkungan. Keempat, domain transendental meliputi hubungan diri sendiri dengan sesuatu yang melewati aspek manusia, seperti kepedulian puncak, kekuatan kosmis dan realitas transenden (Fisher, 2011; Fisher \& Ng, 2017).

Konsep spiritual well-being yang diungkapkan oleh Fisher ini tidak lepas dari kerangka defenisi spiritual well-being yang dikemukakan oleh National Interfaith Coalition on Aging (NICA) di Washington DC yang mengatakan spiritual well-being sebagai "the affirmation of life in a relationship with God, self, community and environtment that nurtures 
Hubungan Spiritual Well-Being | Raja Oloan Tumanggor, Heni Mularsih

and celebrates wholeness". Dalam defenisi tersebut kesehatan spiritual dilukiskan sebagai sebuah dimensi mendasar dari semua aspek kesehatan dan kesejahteraan seseorang yang mengintegrasikan semua dimensi kesehatan yang lain seperti kesehatan fisik, mental, emosional, dan sosial. Kesehatan spiritual merupakan sebuah keadaan yang dinamis, dimana manusia mampu hidup secara harmonis dalam berelasi dengan diri sendiri, sesama, lingkungan, dan Tuhan (Fisher, 2010). Artinya, relasiku dengan diri sendiri, sesama, lingkungan dan Tuhan menjadi indikator penting dalam menentukan apakah saya memiliki kesejahteraan spiritual yang baik atau tidak. Hal ini penting diperhatikan karena banyak orang kerap menilai aspek relasi dengan diri sendiri, sesama dan lingkungan sebagai hal berbeda dengan relasi dengan Tuhan.

\section{METODE}

Metode penelitian ini adalah metode kuantitatif non eksperimental. Karakteristik subjek penelitian ini adalah 1113 orang kaum remaja baik laki-laki maupun perempuan dari rentang usia 13 hingga 21 tahun. Bentuk alat ukur yang dipakai dalam penelitian ini adalah kuesioner. Ada tiga kuosioner yang digunakan untuk mengambil data penelitian, yaitu skala spiritual well-being, kecerdasan emosi dan sikap toleransi. Skala spiritual wellbeing yang dipakai adalah hasil penyesuaian Spiritual Health and Life-Orientation Measure (SHALOM) dari Fisher (2010). Skala ini terdiri dari 20 item yang terdiri dari domain personal (5 item), komunal (5 item), lingkungan (5 item) dan transendental (5 item). Skala kecerdasan emosi mengacu pada Goleman (1995) yang terdiri dari 40 butir meliputi lima komponen yaitu kesadaran diri/intrapersonal (7 item), kesadaran antar pribadi (14 item), penyesuaian diri (11 item), manajemen stres (3 item), dan suasana hati (5 item).

Kuosioner sikap toleransi yang digunakan merupakan hasil adaptasi dari skala karakter toleransi yang disusun oleh Supriyanto dan Wahyudi (2017) yang mendasarkan diri pada penelitian Galtung dan Fischer (2013) mengenai konsep perdamaian dan teori karakter toleransi dari (Tillman, 2004). Skala sikap toleransi ini disusun berdasarkan tiga aspek, yaitu pertama: kedamaian (12 item), kedua: menghargai perbedaan dan individu (12 item), ketiga: kesadaran (15). Kedamaian memiliki indikator toleransi berupa peduli, ketidaktakutan, dan cinta. Menghargai perbedaan mempunyai indikator toleransi berupa saling menghargai satu sama lain, menghargai perbedaan orang lain, dan menghargai diri sendiri. Sedangkan kesadaran memiliki indikator berupa menghargai kebaikan orang lain, terbuka, reseptif, kenyamanan dalam kehidupan, dan kenyamanan dengan orang lain. Kuosioner sikap toleransi berjumlah 39 butir. Jadi total alat ukur ini memiliki 99 item. Alat ukur itu diujicoba pada 150 orang subjek untuk mengetahui validitas dan reliabilitasnya. 
Alat ukur yang sudah valid dan reliabel digunakan untuk mengumpulkan data di lima kota dari lima propinsi di Indonesia. Lokasi penelitian ada di lima kota, yaitu: Jakarta (DKI), Bandar Jaya (Lampung), Bekasi (Jawa Barat), Klaten (Jawa Tengah), dan Siborong-borong (Sumut). Masing-masing kota dikunjungi selama 3 hari untuk pengambilan data.

Ada tiga variabel dalam penelitian ini yaitu spiritual well-being, kecerdasan emosi dan sikap toleransi. Spiritual well-being adalah kondisi sejahtera secara spiritual yang berpengaruh terhadap aspek kehidupan. Kondisi sejahtera secara spiritual ini berhubungan dengan relasi individu dengan diri sendiri, dengan sesama/komunitas, lingkungan dan dengan Tuhan. Kecerdasan emosi merupakan suatu situasi dimana orang mengalami keberhasilan hidup dan memiliki kesadaran terhadap diri sendiri dan orang lain. Faktor yang dominan menyokong kesuksesan seseorang adalah kecerdasan emosi. Sementara faktor kognitif hanya menyumbang kira-kira 20 persen. Sikap toleransi adalah suatu sikap lapang dada terhadap prinsip orang lain, tanpa mengorbankan prinsip sendiri yang dianutnya, melainkan memiliki sikap kuat atas keyakinan dan pendapat sendiri. Dengan sikap toleransi orang mampu menahan hal yang tidak disukai dalam rangka membangun hubungan sosial yang lebih baik. Toleransi mengandaikan adanya penerimaan dan penghargaan terhadap pandangan, keyakinan, nilai dan prinsip yang berbeda dengan diri kita. Intinya sikap toleransi adalah sikap yang bersedia menerima keanekaragaman karena keberadaan orang lain diakui dan dihormati. Pada prinsipnya sikap toleransi setuju dalam perbedaan. Desain penelitian ini adalah desain korelasional untuk mengetahui hubungan spiritual well-being (X1) terhadap sikap toleransi (Y), hubungan kecerdasan emosi (X2) terhadap sikap toleransi (Y), hubungan spiritual wellbeing (X1) terhadap kecerdasan emosi (X2). Data penelitian dianalisa dengan teknik korelasi. Dalam hal ini analisis dilakukan untuk mengetahui peran variabel spiritual wellbeing terhadap sikap toleransi pada kaum remaja, peran kecerdasan emosi terhadap sikap toleransi bagi kaum remaja dan peran spiritual well-being terhadap kecerdasan emosi bagi kaum remaja.

\section{PAPARAN HASIL}

Karakteristik subjek penelitian ini sebagai berikut. Jumlah subjek dalam penelitian ini sebanyak 1113 orang yang terdiri dari 557 laki-laki (50\%) dan 556 perempuan (50\%). Umur subjek berkisar antara 11 -30 tahun dengan rata-rata subjek berumur 14 tahun, kebanyakan adalah berumur 12-16 tahun (84, 8 \%). Pendidikan didominasi oleh siswa SMP $(56,1 \%)$, kemudian disusul oleh siswa SMA $(27,4 \%)$ dan SD (16,5\%). Dilihat dari etnis/suku dari responden kebanyakan berasal dari etnis Jawa $(35,7 \%)$, kemudian disusul 
Hubungan Spiritual Well-Being | Raja Oloan Tumanggor, Heni Mularsih

oleh Batak (27,4 \%), China (21,4\%), Melayu dan Ambon masing-masing 0,4\%, Lampung 4\%, Betawi 1,5\%, dll (9,3\%). Karakteristik subjek berdasarkan agama kebanyakan menganut agama Protestan (44,3\%), menyusul Islam (32,3 \%), Katolik (14,9\%), Buddha $(7,6 \%)$, Hindu $(0,6 \%)$, dan Khong Hu chu (0,3\%). Sementara karakteristik menurut asal proponsi: Lampung 22,5 \%, Jawa Barat 22,4\%, DKI 20,1\%, Sumut 21,5\%, dan Jawa Tengah $13,6 \%$.

Tabel 1

Gambaran umum karakteristik subjek penelitian

\begin{tabular}{|c|c|c|c|}
\hline DATA PERSONAL & KATEGORI & JUMLAH & PRESENTASI \\
\hline \multirow{2}{*}{ Jenis kelamin } & Laki-laki & 557 & 50 \\
\hline & Perempuan & 556 & 50 \\
\hline \multirow[t]{3}{*}{ Pendidikan } & SD & 184 & 16,5 \\
\hline & SMP & 624 & 56,1 \\
\hline & SMA & 305 & 27,4 \\
\hline \multirow[t]{8}{*}{ Suku } & Melayu & 4 & 0,4 \\
\hline & China & 238 & 21,4 \\
\hline & Jawa & 397 & 35,7 \\
\hline & Batak & 305 & 27,4 \\
\hline & Ambon & 4 & 0,4 \\
\hline & Lampung & 44 & 4 \\
\hline & Betawi & 17 & 1,5 \\
\hline & Lain-lain & 104 & 9,3 \\
\hline \multirow[t]{6}{*}{ Agama } & Islam & 359 & 32,3 \\
\hline & Kris Protestan & 493 & 44,3 \\
\hline & Katolik & 166 & 14,9 \\
\hline & Hindu & 7 & 0,6 \\
\hline & Buddha & 85 & 7,6 \\
\hline & Khong Hu chu & 3 & 0,3 \\
\hline \multirow[t]{2}{*}{ Umur } & 11-16 tahun & 950 & 91,8 \\
\hline & $17-30$ & 163 & 8,2 \\
\hline \multirow[t]{5}{*}{ Asal Propinsi } & DKI & 224 & 20,1 \\
\hline & Jabar & 249 & 22,4 \\
\hline & Lampung & 250 & 22,5 \\
\hline & Jateng & 151 & 13,6 \\
\hline & Sumut & 239 & 21,5 \\
\hline
\end{tabular}

Sebelum mengambil data penelitian yang sesungguhnya, diperlukan alat ukur yang memenuhi persyaratan validitas dan reliabilitas yang baik. Validitas dan reliabilitas alat ukur spiritual well-being bergerak dari skor $r=0,513$ sampai $r=0,849$ dan reliabilitasnya 0,961 . Jadi alat ukur spiritual well-being yang terdiri dari 20 item telah memenuhi validitas dan reliabilitas.

Sementara validitas alat ukur kecerdasan emosi adalah antara $\mathrm{r}=0,305$ hingga $\mathrm{r}=$ 0,705 dengan reliabilitas 0,904 . Jadi alat ukur kecerdasan emosi ini pun telah memenuhi validitas dan reliabilitas yang baik sehingga dapat dipergunakan sebagai alat pengumpulan data yang sebenarnya. Sedangkan validitas alat ukur sikap toleransi 
bergerak antara $r=0,224$ hingga $r=0,665$ dengan reliabilitas pada 0,937. Maka, alat ukur ini pun memiliki syarat validitas dan reliabilitas yang baik.

Sebelum dilakukan uji korelasi perlu ada uji normalitas dan linearitas Nisfiannoor (2013). Melalui uji normalitas dengan menggunakan one-sample Kolmogorov-Smirnov Test diperoleh hasil untuk variabel spiritual well-being $\mathrm{p}=.200$ dengan signifikansi $\mathrm{p}>.05$, yang berarti data terdistribusi normal. Demikian juga variabel kecerdasan emosi memperoleh $\mathrm{p}=.200$ dimana $\mathrm{p}>.05$ yang artinya data variabel ini juga terdistribusi normal. Variabel sikap toleransi juga memperoleh nilai $p=.200$ dimana $p>.05$ yang berarti data terdistribusi normal.

Melalui uji korelasi ditemukan adanya hubungan yang signifikan antara spiritual well-being dengan sikap toleransi $(r=0,844(* *), p=000<0,001)$; terdapat hubungan signifikan antara kecerdasan emosi dengan sikap toleransi ( $r=0,844\left({ }^{* *}\right), p=000<$ 0,001); dan terdapat hubungan yang signifikan antara spiritual well-being dengan kecerdasan emosi $(r=0,836(* *), p=000<0,001)$.

\section{Tabel 2}

\section{Uji Korelasi antara variabel penelitian}

\begin{tabular}{lll}
\hline \multicolumn{1}{c}{ Variabel } & \multicolumn{1}{c}{ Hasil Korelasi } & \multicolumn{1}{c}{ Makna signifikansi } \\
\hline SWB - sik. Toleransi & $r=0,844\left(^{* *}\right), p=000<0,001$ & signifikan \\
\hline KE - sikap toleransi & $r=0,844\left(^{* *}\right), p=000<0,001$ & signifikan \\
\hline SWB - KE & $r=0,836\left(^{* *}\right), p=000<0,001$ & signifikan \\
\hline
\end{tabular}

Selanjutnya hasil analisis uji regresi memperlihatkan bahwa terdapat peran spiritual well-being terhadap sikap toleransi yang signifikan $\left(\mathrm{r}^{2}=.713, \mathrm{t}=11293, \mathrm{p}<\right.$ .001). Nilai $\mathrm{r}^{2}=.713$ menunjukkan bahwa sumbangan spiritual well-being terhadap sikap toleransi sebasar 71,3\%. Jadi masih ada faktor-faktor lain sebesar 28,7 \% yang mempengaruhi sikap toleransi.

Demikian juga hasil analisis regresi menunjukkan bahwa terdapat peran kecerdasan emosi terhadap sikap toleransi $\left(\mathrm{r}^{2}=.712, \mathrm{t}=-5102, \mathrm{p}<.001\right)$. Nilai $\mathrm{r}^{2}=.712$ menunjukkan bahwa sumbangan kecerdasan emosi terhadap sikap toleransi sebesar $71,2 \%$, dan masih ada faktor lain sebesar $28,8 \%$ yang mempengaruhi sikap toleransi.

Dari hasil analisis regresi juga diketahui adanya peran spiritual well-being terhadap kecerdasan emosi $\left(r^{2}=.699, t=30896, p<.001\right)$. Nilai $r^{2}=.699$ menunjukkan bahwa sumbangan spiritual well-being terhadap kecerdasan emosi sebesar 69,9\% dan sisanya sebesar 30,1 \% faktor lain yang mempengaruhi kecerdasan emosi. Demikian juga diketahui ada peran spiritual well-being dan kecerdasan emosi terhadap sikap toleransi $\left(\mathrm{r}^{2}\right.$ 
Hubungan Spiritual Well-Being | Raja Oloan Tumanggor, Heni Mularsih

$=.776, \mathrm{~F}=1921,885, \mathrm{p}=.000, \mathrm{p}<.01)$. Nilai $\mathrm{r}^{2}=.776$ menunjukkan bahwa sumbangan spiritual well-being dan kecerdasan emosi pada sikap toleransi sebesar 77,6 \% dan sisanya sebesar $22,4 \%$ faktor lain yang mempengaruhi sikap toleransi.

Tabel 3

Hasil Uji Regresi antar variabel penelitian

Antar variabel Sumbangan

SWB - sik. toleransi

$\mathrm{r} 2=.713, \mathrm{t}=11293, \mathrm{p}<.001$

Makna

KE - sikap toleransi

$\mathrm{r} 2=.712, \mathrm{t}=-5102, \mathrm{p}<.001$

Signifikan

SWB - KE

$\mathrm{r} 2=.699, \mathrm{t}=30896, \mathrm{p}<.001$

Signifikan

SWB+KE-sik.toleransi

$\mathrm{r} 2=.776, \mathrm{~F}=1921,885, \mathrm{p}=.000, \mathrm{p}<.01$

Signifikan

signifikan

\section{PEMBAHASAN}

Hasil penelitian ini menunjukkan bahwa ada hubungan signifikan antara spiritual well-being dengan sikap toleransi $\left(\mathrm{r}^{2}=.713, \mathrm{t}=11293, \mathrm{p}<.001\right)$. Artinya bahwa spiritual well-being benar-benar menjadi dasar bagi seseorang dalam membangun sikap toleransi terhadap sesama. Penelitian ini sejalan dengan penelitian Walker (2011) yang menganalisa keterkaitan antara kematangan spiritual dengan toleransi di antara penganut agama Adventis di Jamaica. Dia menguji tingkat toleransi warga adventis di Jamaica. Kesimpulannya adalah toleransi berhubungan dengan kematangan spiritual seseorang. Artinya semakin matang kehidupan spiritual seseorang maka semakin baik juga sikap toleransinya.

Penelitian ini juga sejalan dengan penelitian yang dilakukan oleh Hughes (2013) yang mengungkapkan bahwa orang yang memiliki kesejahteraan spiritual umumnya lebih toleran dari pada orang yang tidak memiliki kesejahteraan spiritual. Hanya saja masalah spiritual tidak selalu berkaitan dengan agama yang dianut. Artinya ada orang yang mengaku spiritual, tapi tidak memeluk satu agama pun. Jadi masalah spiritual harus dibedakan dengan memeluk suatu agama. Walaupun sebenarnya orang yang menganut sebuah agama juga memiliki spiritualitas yang berdasar pada agama tersebut.

Demikian juga terdapat korelasi yang signifikan antara kecerdasan emosi dengan sikap toleransi $\left(\mathrm{r}^{2}=.712, \mathrm{t}=-5102, \mathrm{p}<.001\right)$. Hal ini sejalan dengan penelitian yang dilakukan oleh Ghufron (2016) yang meneliti mahasiswa Pendidikan Agama Islam, Jurusan Tarbiyah, Sekolah Tinggi Agama Islam Kudus, yang menyatakan bahwa ada hubungan positif yang signifikan antara kecerdasan emosi dengan sikap toleransi. Kecerdasan emosi ialah mampunya pribadi untuk memanfaatkan dimensi kecerdasan atau kognitif guna mengolah perasaan yang tampak dalam pengenalan, pemahaman, pengungkapan dan menghargai perasaan orang lain. Kompetensi ini kemudian akan 
berperan pada kompetensi lainnya seperti menyesuaikan diri, tekun, motivasi, mampu bekerja sama dan menjalin hubungan yang berdaya guna dengan orang lain.

Orang yang emosinya cerdas akan bisa memahami situasi emosi sendiri dan emosi orang lain, baik dalam bidang agama, akademik, ekonomi, maupun dalam pekerjaan. Demikian juga orang yang memiliki sikap toleransi yang baik umumnya memiliki kecerdasan emosi yang baik juga, karena individu yang memiliki sikap toleransi yang tinggi memiliki kemampuan untuk mengerti, menghayati dan mewujudkan nilai-nilai yang dipercayainya. Pribadi yang memiliki kecerdasan emosi tinggi mampu menggunakan daya mereka dengan bijaksana, serta sanggup memahami dan bersikap toleran pada orang yang keyakinannya berbeda, serta tidak mau memaksakan orang lain untuk mengikuti keyakinannya.

Jadi ada hubungan positif antara kercerdasan emosi dengan sikap toleransi pada para remaja di lima kota dari lima propinsi. Semakin tinggi kecerdasan emosi para remaja, maka semakin tinggi pula sikap toleransinya. Hasil penelitian ini menunjukkan betapa pentingnya kecerdasan emosi bagi kehidupan kaum remaja. Secara khusus dalam kaitannya dengan kehidupan majemuk misalnya perbedaan suku, bahasa, etnis dan agama.

Hasil penelitian ini juga menunjukkan bahwa terdapat hubungan yang signifikan antara spiritual well-being dengan kecerdasan emosi $\left(\mathrm{r}^{2}=.699, \mathrm{t}=30\right.$ 896, $\left.\mathrm{p}<.001\right)$. Kaum remaja yang memiliki spiritual well-being akan mampu mengendalikan emosinya dalam menjalin relasi dengan sesamanya. Penelitian ini sejalan dengan penelitian Arbabisarjou et al. (2016) yang meneliti hubungan kecerdasan spiritual dengan kecerdasan emosi di antara mahasiswa Ilmu Medis Universitas Isfahan. Menurutnya, kecerdasan spiritual mampu mendorong kecerdasan emosional seseorang, demikian juga kecerdasan emosional memperkokoh kecerdasan spiritual. Berdasarkan temuan ini sangat mungkin merealisasikan hubungan interaktif antara spiritual well-being dengan kecerdasan emosi. Kedua variabel saling berhubungan secara langsung. Dengan kata lain pertumbuhan pada spiritual well-being membantu pada pertumbuhan kecerdasan emosional. Demikian juga kecerdasan emosional mampu memperkokoh kecerdasan spiritual. Kontribusi yang dapat diberikan oleh kecerdasan spiritual dalam memajukan kecerdasan emosioanl adalah bahwa dimensi kecerdasan spiritual seperti kesadaran diri, pengalaman sehari-hari seperti pengalaman religius, doa, keyakinan pada konsep religius, kesabaran dan sikap toleransi bagi yang lain efektif dalam memajukan kecerdasan emosi.

Hubungan yang signifikan antara kecerdasan spiritual dengan kecerdasan emosional juga diteliti oleh Chin et al. 2012) yang meneliti para enterpreneur sukses di 
Hubungan Spiritual Well-Being | Raja Oloan Tumanggor, Heni Mularsih

Malaysia. Menurut Chin et al. (2012) banyak kaum enterpreuner sukses karena memiliki emosi positif dalam dirinya. Hal itu terbukti dari kemampuan mereka untuk berkreasi dan berinovasi. Kecerdasan emosi yang mereka miliki ternyata membuat mereka sukses dalam berbisnis, dan kesuksesan ini bukan hanya untuk diri mereka sendiri, tapi juga untuk orang yang ada disekeliling mereka, antara lain para karyawan dan para pelanggannya. Kecerdasan emosi membuat mereka bisa mengelola dan memanejemen orang sekitarnya untuk sukses bersama. Jadi kecerdasan spiritual dan emosional membuat para enterpreneur menjadi orang yang kreatif dan inovatif dalam membangun kesuksesannya.

Saran teoretis pada penelitian selanjutnya peneliti perlu menggunakan variabel lain misalnya tindakan prososial dalam upaya meningkatkan sikap toleransi bagi kaum remaja. Tindakan prososial seperti meminjamkan barang milik sendiri kepada orang lain, dan mau bekerja sama dalam kelompok, suka menyumbang merupakan bibit-bibit positif dalam membangun sikap toleransi di kalangan para remaja.

Secara praktis para remaja perlu meningkatkan spiritual well-being melalui berbagai aktivitas keagamaan seperti pendalaman rohani secara pribadi, berelasi baik dengan sesama, lingkungan dan khususnya dengan Allah, karena telah terbukti spiritual well-being memiliki peran yang signifikan untuk meningkatkan sikap toleransi di antara kaum remaja. Melalui kehidupan spiritual yang baik kaum muda dapat membangun sikap toleran bagi sesamanya, karena ajaran agama menganjurkan semua orang harus menerima dan mencintari sesama seperti diri sendiri. Demikian juga para remaja perlu membangun kecerdasan emosinya melalui berbagai aktivitas seperti penyesuaian diri, mengelola hati, menghindarkan stres, membina relasi dengan diri sendiri dan sesama. Semuanya ini ternyata berkorelasi penting terhadap sikap toleransi. Bila kaum muda mampu mengelola emosi sebagai buah dari kecerdasan emosinya, maka mereka semakin mampu untuk mengendalikan diri tidak sewenang-wenang terhadap orang lain. Ketidaksewenang-wenangan merupakan buah dan hasil dari sikap toleransi yang dewasa dari kaum muda.

\section{SIMPULAN}

Hasil penelitian ini dapat disimpulkan bahwa ada hubungan yang signifikan spiritual well-being terhadap sikap toleransi pada kaum remaja di lima kota: Jakarta (DKI), Bekasi (Jawa Barat), Bandar Jaya (Bandar Lampung), Klaten (Jawa Tengah), dan Siborongborong (Sumatera Utara); ada hubungan kecerdasan emosi terhadap sikap toleransi pada kaum remaja, dan juga ada hubungan spiritual well-being terhadap kecerdasan emosi bagi kaum remaja. 
Hubungan Spiritual Well-Being | Raja Oloan Tumanggor, Heni Mularsih

\section{UCAPAN TERIMA KASIH}

Kami mengucapkan banyak terimakasih kepada Kementerian Riset, Teknologi dan Pendidikan Tinggi (Kemenristek Dikti) yang telah membiayai penelitian ini untuk tahun anggaran 2019. Kami juga mengucapkan terimakasih kepada Direktorat Penelitian dan Pengabdian Masyarakat (DPPM) Universitas Tarumanagara Jakarta yang telah memfasilitasi kami untuk melakukan penelitian ini.

\section{DAFTAR PUSTAKA}

Arbabisarjou, A., Hesabi, N., Homaei, R., Omeidi, K., Ghaljaei, F., \& Arish, N. (2016). The Relationship between Spiritual Intelligence and Emotional Intelligence among Students at Isfahan University of Medical Sciences with a Concentration on Improvement of Social Relations. 8.

Bahari (Ed.). (2010). Toleransi beragama mahasiswa: Studi tentang pengaruh kepribadian, keterlibatan organisasi, hasil belajar pendidikan agama, dan lingkungan pendidikan terhadap toleransi mahasiswa berbeda agama pada 7 perguruan tinggi umum negeri (Cet. 1). Kementerian Agama RI, Badan Litbang dan Diklat, Puslitbang Kehidupan Keagamaan.

Bufford, R. K., Paloutzian, R. F., \& Ellison, C. W. (2018). Norms for the Spiritual Weil-Being Scale: Journal of Psychology andTheology. https://doi.org/10.1177/009164719101900106

Chin, S. T. S., Raman, K., Yeow, J. A., \& Eze, U. C. (2012). Relationship Between Emotional Intelligence And Spiritual Intelligence In Nurturing Creativity And Innovation Among Successful Entrepreneurs: A Conceptual Framework. Procedia - Social and Behavioral Sciences, 57, 261-267. https://doi.org/10.1016/j.sbspro.2012.09.1184

Ellison, C. W. (1983). Spiritual well-being: Conceptualization and measurement. Journal of $\begin{array}{llll}\text { Psychology } \quad \text { and 330-340. } & \text { Theology, }\end{array}$ https://doi.org/10.1177/009164718301100406

Fisher, J. (2010). Development and Application of a Spiritual Well-Being Questionnaire Called SHALOM. Religions, 1(1), 105-121. https://doi.org/10.3390/rel1010105

Fisher, J. (2011). The Four Domains Model: Connecting Spirituality, Health and Well-Being. Religions, 2(1), 17-28. https://doi.org/10.3390/rel2010017

Fisher, J., \& Ng, D. (2017). Presenting a 4-Item Spiritual Well-Being Index (4-ISWBI). Religions, 8(9), 179. https://doi.org/10.3390/rel8090179

Galtung, J., \& Fischer, D. (2013). Positive and Negative Peace. In J. Galtung \& D. Fischer, Johan Galtung (Vol. 5, pp. 173-178). Springer Berlin Heidelberg. https://doi.org/10.1007/978-3-642-32481-9_17

Gerintya, S. (2018). Benarkah Intoleransi Antar-umat Beragama Meningkat? tirto.id. https://tirto.id/benarkah-intoleransi-antar-umat-beragama-meningkat-cEPz 
Hubungan Spiritual Well-Being | Raja Oloan Tumanggor, Heni Mularsih

Ghufron, M. N. (2016). Peran Kecerdasan Emosi dalam Meningkatkan Toleransi Beragama. FIKRAH, 4(1), 138. https://doi.org/10.21043/fikrah.v4i1.1664

Goleman, D. (1995). Emotional Intelligence. Bantam Books.

Hughes, P. (2013). Spirituality and Religious Tolerance. Implicit Religion,16(1),65-91. https://doi.org/10.1558/imre.v16i1.65

Khisbiyah, Y. (2007). Menepis prasangka, memupuk toleransi untuk multikulturalisme: Dukungan dari psikologi sosial. Surakarta: PSB-PS UMS.

Nisfiannoor, M. (2013). Pendekatan Statistika Modern. Usakti.

Rumini, S., \& Sundari H.S., S. (2004). Perkembangan Anak dan Remaja. Rineka Cipta.

Santrock, J. W. (2003). Adolescence. McGraw-Hill.

Supriyanto, A., \& Wahyudi, A. (2017). Skala karakter toleransi: Konsep dan operasional aspek kedamaian, menghargai perbedaan dan kesadaran individu. Counsellia: $\begin{array}{llll}\text { Jurnal Bimbingan dan Konseling, } & 7(2), & 61 .\end{array}$ https://doi.org/10.25273/counsellia.v7i2.1710

Tillman, D. (2004). Pendidikan nilai untuk kaum dewasa-muda. Grasindo.

Walker, M. D. (2011). Religious Tolerance and its Relationship to Spiritual Maturity and Religious Orientation Among Seventh-day Adventists in Jamaica. 273. 